\title{
Whiteflies on Landscape Ornamentals ${ }^{1}$
}

\author{
E. A. Buss ${ }^{2}$
}

Whiteflies are common pests on many ornamental plants. Some of the most economically important species in Florida are the silverleaf whitefly, fig or ficus whitefly, citrus whitefly, and the rugose spiraling whitefly. The most frequently attacked plants include allamanda, avocado, chinaberry, citrus, fig, fringe tree, gardenia, gumbo limbo, ligustrum, mango, various palms, persimmon, viburnum, and many annuals.

Adult whiteflies (Figure 1) look like tiny white moths, but are more closely related to scale insects. Most are about $1 / 16$ inch long and have four wings. The wings and body are covered with a fine white powdery wax. Reliable identifications are based on the adults. The immature whiteflies (nymphs) typically occur on the undersides of leaves, are flat, oval in outline, and slightly smaller than a pin head. Some species are light green to whitish and somewhat transparent (Figure 2). Others are black in the center and have a white waxy fringe around the edge.

A generalized life cycle of the whitefly is as follows: The eggs are laid on the undersides of the leaves and hatch in 4 to 12 days into active, six legged nymphs (crawlers). The crawlers move around for several hours, then insert their mouthparts into the leaves and stay there. After molting three times, they pupate and then become adults. The pupal case remains on the plant tissue even after the adult has emerged. How long it takes for the insects to develop from eggs to adults varies from 4 weeks (summer) to 6 months (winter).

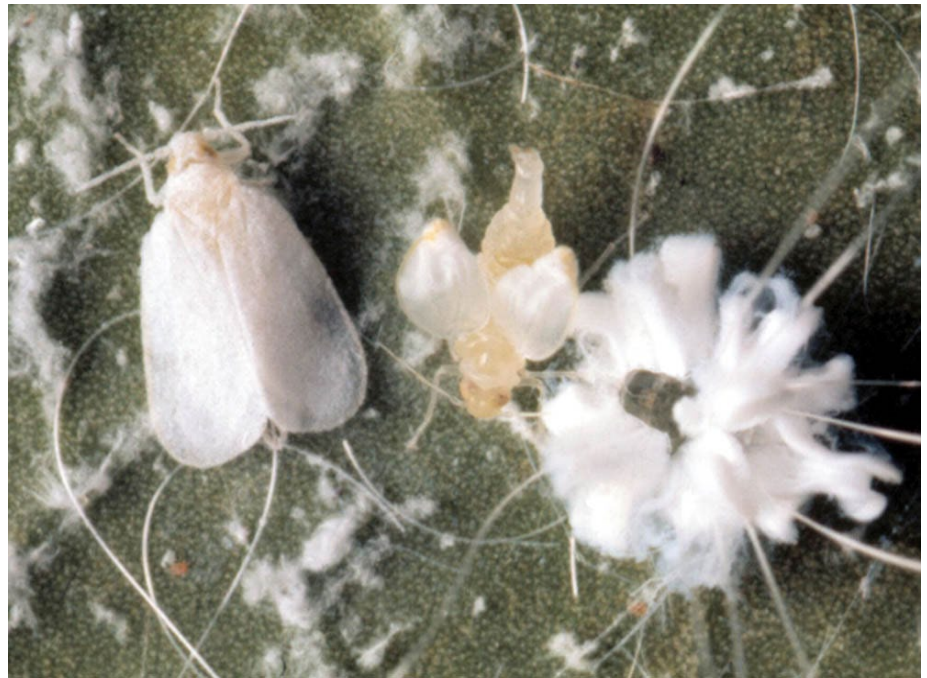

Figure 1. Spiraling whitefly adult.

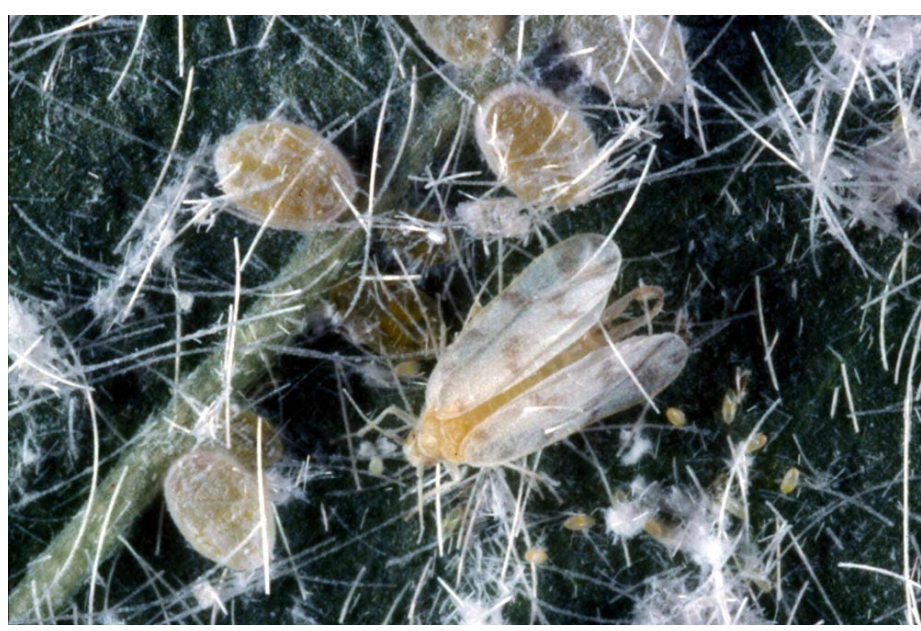

Figure 2. Giant whitefly adult and nymphs.

1. This document is ENY-317, one of a series of the Entomology and Nematology Department, UF/IFAS Extension. Original publication date October 1993. Revised March 2013. Visit the EDIS website at http://edis.ifas.ufl.edu.

2. E. A. Buss, associate professor, Entomology and Nematology Department, UF/IFAS Extension, Gainesville, FL 32611.

The use of trade names in this publication is solely for the purpose of providing specific information. UF/IFAS does not guarantee or warranty the products named, and references to them in this publication do not signify our approval to the exclusion of other products of suitable composition. 
Whiteflies have piercing-sucking (needle-like) mouthparts with which they puncture the leaf and suck the plant fluids. The top sides of leaves on infested plants become pale or spotted due to these insects feeding on the undersides of the leaves. Oftentimes an infestation goes unnoticed until leaves turn yellow or drop unexpectedly, or until an infested plant is disturbed and small clouds of whiteflies emerge from it. Some whitefly species can cause greater damage by transmitting plant viruses.

Whiteflies (as well as soft scales, mealybugs, and aphids) excrete a sugary substance called honeydew, and an unsightly black fungus called sooty mold grows on the honeydew. Besides being unattractive, sooty mold may interfere with photosynthesis, reduce plant growth, and cause early leaf drop. Sooty mold usually weathers away after an insect infestation is controlled. Ants also feed on the honeydew, so if ants become a problem, plants should be examined closely for these sucking pests.

\section{Biological Control}

Citrus whitefly nymphs (Figure 3), one of the more common whitefly species attacking ornamental plants other than citrus, are highly parasitized by a small wasp, Prospaltella lahorensis. Citrus is the primary host of the cloudy winged whitefly, a species closely related to the citrus whitefly. Populations of citrus blackfly are also suppressed throughout the state by two tiny wasps. Certain predatory mites and lady beetles (lady bugs) also help suppress pest populations.

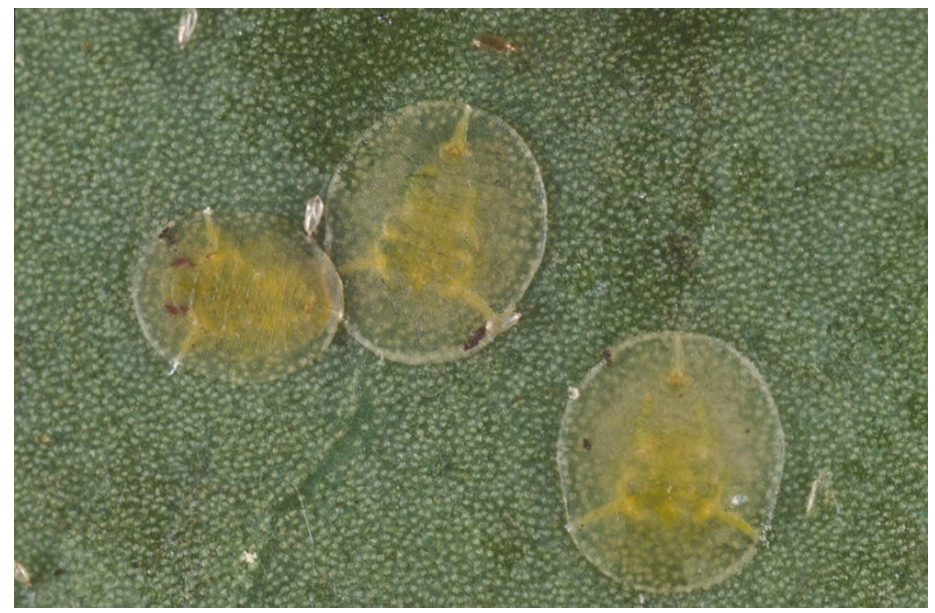

Figure 3. Citrus whitefly nymphs.

Credits: Lyle Buss, University of Florida

Carefully examine infested plants for evidence of parasitism. Parasitized whitefly nymphs will contain the larva or pupa of the parasitoid or an emergence hole may be visible on a nymph. The parasitoid does not attack the adult whitefly. If parasitism is evident, minimize the use of contact insecticides so the natural enemies have a chance to get better established.

Some whiteflies may also be naturally attacked by beneficial fungi (Paecilomyces) (Figure 4).

The silverleaf (sweet potato) whitefly replaced the citrus whitefly within the last 15-20 years as the most damaging whitefly species attacking ornamental plants. This whitefly is not strongly parasitized and is tough to control with insecticides. This species is not attacked by Prospaltella lahorensis. However, new invasive pests keep entering Florida and are currently causing considerable aesthetic damage.

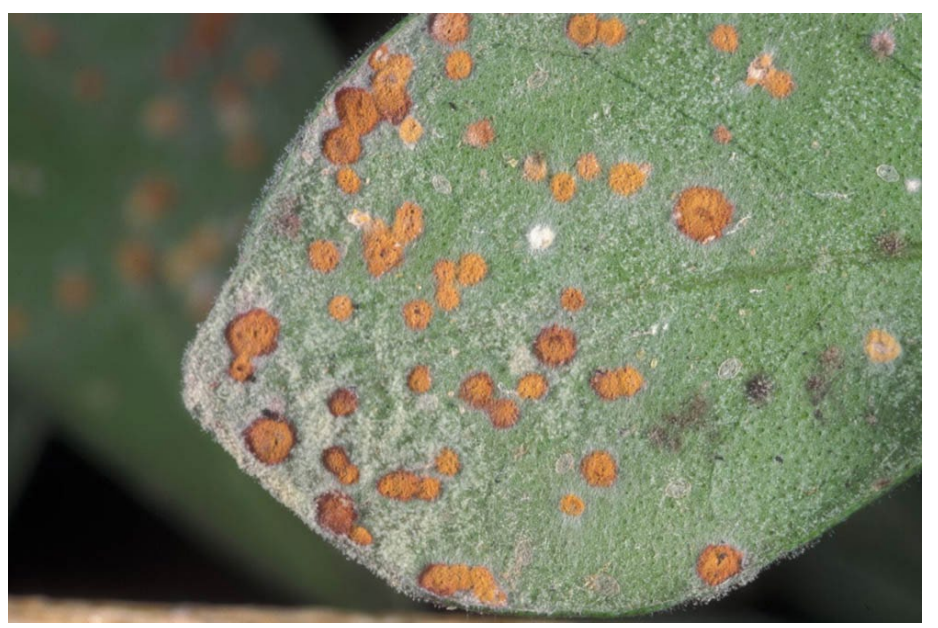

Figure 4. Infected whiteflies.

Credits: Lyle Buss, University of Florida

\section{Chemical Control}

Insecticides that are labeled for whitefly control by homeowners are listed in Table 1, and professional products are listed in Table 2.

The first type of product to try is an insecticidal soap or horticultural oil spray. These products are safer for people, animals, and the environment, but they can still kill whitefly natural enemies. Be sure to read and understand the label instructions before doing any applications. If spraying, thorough coverage on the undersides of the leaves to the point of run-off is especially important. Repeat at weekly intervals as needed.

For synthetic insecticides, be very cautious of overusing the chemical class of neonicotinoids because of the possibility of developing pesticide resistance. Foliar applications tend to be with contact insecticides like pyrethroids. Foliar applications may provide quick control, but do not provide 
longterm control. Contact insecticides will also disrupt natural enemies and should be used selectively. Other application options include basal bark sprays, granular broadcast applications, tree injections, and soil drenches or injections. The active ingredient of a commonly used systemic insecticide is imidacloprid (ie., Merit, Marathon), but many other products are effective at reducing whitefly populations.

\section{For More Information}

- Florida Whitefly: http://www.flwhitefly.org

- FDACS website: http://www.freshfromflorida.com/ Divisions-Offices/Plant-Industry/Pests-Diseases/ Whiteflies-Found-in-Florida

- FDACS Pest Alert http://www.freshfromflorida.com/Divisions-Offices/Plant-Industry/ Plant-Industry-Publications/Pest-Alerts

- Solutions for Your Life (http://solutionsforyourlife.ufl. edu/hot_topics/agriculture/whiteflies.html)
- Factsheets on the fig whitefly:

1.http://mrec.ifas.ufl.edu/lso/IAWG/FIG/The\%20Fig\%20 Whitefly.htm

2.http://miami-dade.ifas.ufl.edu/pdfs/urban_hort/ Ficus\%20whitefly\%20flier\%20updated\%2008.pdf

- Factsheets on the rugose spiraling whitefly on gumbo limbo (http://miami-dade.ifas.ufl.edu/documents/ Thegumbolimbospiralingwhiteflyfactsheet.pdf)

- Entomology and IPM for Foliage Plants (http://www. mrec.ifas.ufl.edu/LSO/bemisia/bemisia.htm)

- Insecticide Resistance Action Committee Website (IRAC) (http://www.irac-online.org)

- Whitefly Knowledgebase (http://entomology.ifas.ufl.edu/ fasulo/whiteflies

Table 1. Insecticides labeled for non-commercial (homeowner) use against whiteflies in Florida.

\begin{tabular}{|c|c|c|}
\hline Active Ingredient & Trade Name & Chemical Class \\
\hline Bifenthrin & $\begin{array}{l}\text { Ortho Bug-B-Gon Max Lawn \& Garden } \\
\text { Insect Killer }\end{array}$ & Pyrethroid \\
\hline Cyfluthrin & $\begin{array}{l}\text { Bayer Advanced Rose \& Flower Insect } \\
\text { Killer } \\
\text { Schultz Lawn \& Garden Insect Killer }\end{array}$ & Pyrethroid \\
\hline Imidacloprid & $\begin{array}{l}\text { Bayer Advanced Lawn Complete Insect } \\
\text { Killer } \\
\text { Bayer Advanced Tree \& Shrub Insect } \\
\text { Control }\end{array}$ & Neonicotinoid \\
\hline Lambda-cyhalothrin & $\begin{array}{l}\text { Spectracide Triazicide Once \& Done Insect } \\
\text { Killer }\end{array}$ & Pyrethroid \\
\hline Malathion & $\begin{array}{l}\text { Green Light Malathion } \\
\text { Ortho Malathion Plus Insect Spray }\end{array}$ & Organophosphate \\
\hline Neem oil & $\begin{array}{l}\text { Bonide Safer BioNeem } \\
\text { Green Light Neem } \\
\text { Green Light Rose Defense } \\
\text { Southern Ag Triple Action Neem Oil }\end{array}$ & Botanical \\
\hline Paraffinic oil & Sun Spray Horticultural Oil & Biorational \\
\hline Permethrin & $\begin{array}{l}\text { Hi-Yield Indoor/Outdoor Broad Use } \\
\text { Insecticide }\end{array}$ & Pyrethroid \\
\hline Potassium salts & Safer's Insecticidal Soap & Biorational \\
\hline Pyrethrins & $\begin{array}{l}\text { Bonide Yard \& Garden Insect Killer } \\
\text { Spectracide Rose \& Flower Insect Spray }\end{array}$ & Botanical \\
\hline
\end{tabular}


Table 2. Insecticides suggested for professional use against whiteflies on Florida ornamentals.

\begin{tabular}{|c|c|c|c|}
\hline Active Ingredient & Trade Name & Chemical Class & IRAC Class \\
\hline Abamectin & Avid & Avermectins & 6 \\
\hline Acetamiprid & TriStar & Neonicotinoid & 4 \\
\hline Azadirachtin & Azatin XL, Azatrol & Botanical & 26 \\
\hline Beauveria bassiana & Botanigard & Microbial & $\mathrm{N} / \mathrm{A}$ \\
\hline Bifenthrin & Bifenthrin Pro, Onyx, Talstar & Pyrethroid & 3 \\
\hline Bifenthrin + clothianidin & Aloft & Pyrethroid + Neonicotinoid & 3,4 \\
\hline Bifenthrin + imidacloprid & Allectus & Pyrethroid + Neonicotinoid & 3,4 \\
\hline Buprofezin & Talus* & IGR & 16 \\
\hline Clothianidin & Arena, Aloft & Neonicotinoid & 4 \\
\hline Cyfluthrin + imidacloprid & Discus & Pyrethroid + Neonicotinoid & 3,4 \\
\hline Dinotefuran & Safari, Zylam & Neonicotinoid & 4 \\
\hline Flonicamid & Aria* & Antifeedant & $9 \mathrm{C}$ \\
\hline Imidacloprid & Marathon*, Merit & Neonicotinoid & 4 \\
\hline Paraffinic Oil & Horticultural Oil & Oil & N/A \\
\hline Potassium Salts of Fatty Acids & Insecticidal Soap & Soap & $\mathrm{N} / \mathrm{A}$ \\
\hline Pymetrozine & Endeavor & Antifeedant & $9 \mathrm{~B}$ \\
\hline Pyridaben & Sanmite & Acaricide & 21 \\
\hline Pyriproxyfen & Distance & IGR & 21 \\
\hline Spiromesifen & Forbid 4F, Judo* & IGR & 23 \\
\hline Spirotetramat & Kontos* & IGR & 23 \\
\hline Thiamethoxam & Flagship & Neonicotinoid & 4 \\
\hline \multicolumn{4}{|c|}{$\begin{array}{l}\text { * For production nursery, greenhouse and/or interiorscape use only. } \\
\text { The inclusion of a trade name does not imply that the University of Florida endorses that particular product, nor does the omission of a } \\
\text { product imply that other products do not work. Information included in these tables is obtained from insecticide trial reports, peer-reviewec } \\
\text { publications, product labels, and the experience of subject matter experts. }\end{array}$} \\
\hline
\end{tabular}

